\title{
Can nature tourism help finance protected areas in the Congo Basin?
}

\author{
David S. Wilkie and Julia F. Carpenter
}

\begin{abstract}
In the debt-ridden, high-population-growth, resource-mining states of the Congo Basin, conservation of biodiversity is seldom the primary concern of national policy makers or of local resource users. Moreover, the recurring costs of managing protected areas and the opportunity costs of forgoing logging and farming to maintain protected areas are a substantial net drain on national and local economies. Consequently, it is becoming increasingly important that protected areas generate, from user fees or donor contributions, sufficient funds to offset the costs of maintaining them. Government and donor investment currently meet less than 30 per cent of the estimated recurring costs required to manage the protected-area network within central African countries effectively, and cover none of the growing opportunity costs.
\end{abstract}

\section{Introduction}

Protected areas in the six nations of central Africa (Republic of Cameroon, Central African Republic, Republic of Congo, Democratic Republic of Congo (DRC), Equatorial Guinea and Gabon) cover c. 230,710 sq kmsome 6 per cent of the region. Estimated recurring costs to manage* this network of protected areas effectively exceed \$US32 million per year (Wilkie \& Carpenter, in press), an amount that Congo Basin countries are unlikely to want to spend, given budget constraints and national priorities that are focused on economic development rather than biodiversity conservation.

\footnotetext{
* In this paper, recurring costs per sq $\mathrm{km}$ to manage a protected area effectively are assumed to be $=\$ \mathrm{US50} \times(1+2 / A+3 / \sqrt{ } A)$, where $A=$ area in $1000 \mathrm{~s}$ of $\mathrm{sq} \mathrm{km}$. Level of investment is based on the total cost to support enough staff to regulate the use of resources within the protected area (i.e. prevent the unsustainable use of resources and thus manage the area effectively. The equation was derived from data from national parks in southern Africa by Africa Resources Trust (ART, 1998).
}

David S. Wilkie (corresponding author) 18 Clark Lane, Waltham, MA 02451-1823, USA. Tel.: + 1781894 9605; fax: + 16175520523 ; e-mail: dwilkie@msn.com

Julia Carpenter 68 High Street, Winchester, MA 01890, USA. Tel.: +1781729 6078; e-mail: jcarpen1@ix.netcom.com

Received 1 September 1998. Accepted 12 May 1999
Nature tourism, the fastest growing sector of the \$US3 trillion ( 3 million million) a year global tourism industry, may offer a source of revenue to help fill this gap in funds. Congo Basin national parks and reserves harbour many charismatic animals (okapi, lowland gorilla, mandrills, bongo, forest elephant) that are likely to attract tourists, and as a result many protected-area managers are sinking capital into the development of tourist infrastructure. This paper reviews the evidence for ecotourism's capacity to generate revenue for protected-area management and appraises the financial viability of nature tourism in the Congo Basin.

Keywords Congo Basin, conservation, protected areas, tourism.

Exact figures for all current expenditures on protected areas by Congo Basin governments and donors are not available. The example of Republic of Cameroon is, however, probably illustrative of the region's 'willingness-to-pay' for biodiversity conservation. Cameroon contributes only $\$$ US143,325 of the estimated $\$ U S 1,901,893$ required for personnel and equipment to manage its current protected area network effectively (Culverwell, 1998). This is equivalent to 0.012 percent of the national annual budget of $\$$ US1.2 billion and places Cameroon near the bottom in expenditure on protected areas when compared with other nations. For example, Germany allocates 0.01 per cent of its national annual budget to protected areas, the Netherlands 0.02 per cent, Malawi 0.13 per cent, USA 0.16 per cent, Tanzania 0.26 per cent and Kenya 0.77 per cent (ART, 1998). Cameroon spends 1 cent per capita on protected areas, compared with the USA's \$US7.7 per capita. Even controlling for differences in per capita GNP, Cameroonians spend proportionally less on protected-area management than do citizens of the US.

Not only are Congo Basin governments unwilling or unable to pay for protected-area management, they may be increasingly unwilling to incur the significant opportunity costs associated with setting aside protected areas, particularly given the rise in timber prices and the continuing need for nations to trade themselves out of debt. A recent World Bank-sponsored auction of 
logging concession rights in Cameroon showed that timber companies were willing to pay the government, on average, \$US4/ha/year (range \$US0.7-8.8/ha/year) for access to old-growth trees (J. Brunner, pers. comm.). A quick calculation suggests that for the Korup, Campo, Dja and Banyang Mbo protected areas alone, the government of Cameroon is forgoing, on average, \$US4 million in potential logging revenue each year, and maybe as much as \$US8 million a year. If other taxes on timber are included, the opportunity costs of maintaining protected areas that contain commercially valuable trees rises to $\$$ US15/ha/year. This translates to \$US14 million dollars per year of lost government revenue to keep Korup, Campo, Dja and Banyang Mbo protected areas free from logging. Even if old-growth forest logging is viable only for $10-15$ years, the total lost revenue associated with excluding logging from these four protected areas (\$US140-210 million) is substantial relative to Cameroon's GDP. These opportunity costs are comparable to those presented by Ruitenbeek (1992), who calculated that 'the rest of the world' would have to pay Cameroon more than $\$ U S 12.7 /$ ha/ year-approximately \$US1.6 million/year, to offset the direct and opportunity costs incurred to maintain Korup National Park as a protected area.

Even in Kenya, where protected areas generate substantial flows of revenue through ecotourism, NortonGriffiths (1995, 1997) and Norton-Griffiths \& Southey (1995) showed that they constitute a net cost to the Kenyan government and the Kenyan people. Kenya could generate gross annual revenues of \$US565 million and net returns of \$US203 million while employing 4.2 million Kenyans if all protected areas were converted to agriculture. This compares with net revenues of only \$US42 million per year from tourism (NortonGriffiths \& Southey, 1995). Eighteen of the 22 parks and reserves in Kenya would generate higher revenues per hectare if they were converted from protected areas and a reliance on tourism, to agriculture and livestock raising (Byrne et al., 1996). Not unlike the situation in central Africa, the opportunity costs of maintaining Kenya's protected-area system are substantial, amounting to almost 3 per cent of GDP (Norton-Griffiths \& Southey, 1995).

Despite the putative and somewhat intangible value of ecological services generated by protected areas, most governments of the Congo Basin regard protected areas that incur immediate and tangible management and opportunity costs as a drain on national treasuries. Unless new sources of revenue are found, parks and reserves will continue to be under-funded, and governments will be tempted to allow or overlook illegal, but lucrative, activities such as logging, bushmeat hunting, and gold or diamond mining within protected areas.

\section{A realist's view of ecotourism potential in the Congo Basin}

Although information on the management costs, and level of government and donor investment in protected areas in the Congo Basin is sparse (Wilkie \& Carpenter, in press), few national protected-area networks receive sufficient financing for effective management (Tables 1 and 2).

Similarly, little information is available on capital investments to establish a tourist infrastructure, the costs of maintaining tourist facilities, or the revenue generated by tourism. To help assess the relative costs and benefits of tourism within the protected areas of the Congo Basin, we have relied on information generously provided by the World Wildlife Fund-US, the Wildlife Conservation Society and Ecosystème Forestiers d'Afrique Centrale (ECOFAC), a regional programme funded by the European Union. The following is a brief analysis of the expected rate of return from tourism in the Dzanga-Sangha protected area of the Central African Republic, with additional information for other protected areas in the region.
Table 1 Estimated annual recurring costs and actual donor spending on a sample of protected areas in the Congo Basin

\begin{tabular}{|c|c|c|c|}
\hline Protected area & $\begin{array}{l}\text { Area } \\
\text { (ha) }\end{array}$ & $\begin{array}{l}\text { Annual } \\
\text { recurring } \\
\text { costs } \\
\left(\$ \mathrm{US}^{*}\right)^{*}\end{array}$ & $\begin{array}{l}\text { Donor } \\
\text { spending } \\
\text { (\$US)t }\end{array}$ \\
\hline Dzanga-Sangha, Central African Republic & 457,000 & 914,000 & 555,000 \\
\hline Lopé, Gabon & 500,000 & $1,000,000$ & 631,560 \\
\hline Odzala, Congo & 280,000 & 560,000 & 864,240 \\
\hline Dja, Cameroon & 526,000 & $1,052,000$ & 664,800 \\
\hline Monte Allen, Equatorial Guinea & 70,000 & 140,000 & 249,300 \\
\hline
\end{tabular}

Source: A. Blom \& C. Aveling (pers. comms).

* ART estimate.

t Average annual spending in the 1990s. 


\begin{tabular}{lrrr}
\hline Country & $\begin{array}{l}\text { Recurring } \\
\text { costs } \\
(\$ \mathrm{US})^{*}\end{array}$ & $\begin{array}{l}\text { Government } \\
\text { spending } \\
(\$ \mathrm{US}) \dagger\end{array}$ & $\begin{array}{l}\text { Donor } \\
\text { spending } \\
(\$ \mathrm{US}) \ddagger\end{array}$ \\
\hline Cameroon & $4,700,000$ & 146,300 & $1,590,723$ \\
Central African Republic & $8,900,000$ & 46,100 & 778,149 \\
Republic of Congo & $11,400,000$ & 148,800 & $2,614,414$ \\
Democratic Republic of Congo & $1,100,000$ & 47,700 & 394,803 \\
Equatorial Guinea & $4,100,000$ & 19,200 & 386,370 \\
Gabon & $2,800,000$ & 34,400 & $1,266,896$ \\
\hline
\end{tabular}

Table 2 Estimated recurring costs and actual spending on Congo Basin protected areas per year in the $1990 \mathrm{~s}$

* Estimates based on total area of protected areas using an equation developed by Africa Resources Trust (ART, 1998).

† Includes only government contribution to donor-sponsored projects.

$\ddagger$ Includes information from ECOFAC, USAID, WCS, World Bank, WWF-US and other donors.

\section{Costs and benefits of ecotourism in the Dzanga-Sangha protected area, Central African Republic}

Dzanga-Sangha, in the south-western dense forest region of the Central African Republic, has good tourist facilities, and tourists can be almost assured of seeing lowland gorilla Gorilla gorilla gorilla on escorted forest walks, and forest elephant Loxodonta africana and bongo Tragelaphus eurycerus from a 10-m high, 25-m long, covered wooden platform located at the edge of a large open salt-lick in the forest.

For the 3 years since records began in 1993, revenue from entrance fees, equipment rentals, tourist services and souvenir sales have averaged $\$$ US12,493 per year (Table 3). Forty per cent of entrance fees are allocated to a local non-governmental organization (NGO) for community development activities, and 10 per cent to a national forestry and tourism fund to help offset costs in other national parks. All other tourist revenue (50 per cent of entrance fees and all net sales of services and souvenirs) is allocated to park management (equivalent to 78.1 per cent of all tourist revenues since 1993; Table 3). These figures do not include revenues generated by tourist spending in the 15-room, 60-bed Doli lodge, which was recently constructed in the protected area at Bayanga. However, visitor spending barely covers hotel operating costs (A. Blom, pers. comm.), and unless visitation rates increase the hotel is unlikely to generate significant revenue.

Tourist fees currently cover, for the first time, the recurring costs of providing tourist services at DzangaSangha. However, revenue from tourism is unlikely to recoup the capital that has been invested in infrastructure development, unless visitation rates and fees increase substantially. The cost of constructing the wildlife viewing mirador, excluding the value of the lumber that was donated by the logging concession Slovenia Bois, was CFA400,000 (\$US1600-based on actual pre-devaluation exchange rates). Building the Doli lodge/hotel cost approximately DM700,000 (\$US391,000). Assuming, conservatively, that tourist visitation remains at 1995 levels (c. 1000 people per year) and continues to generate $\$ U S 20,512$ per year, the internal rate of return (IRRt) of tourism from 1992 to the end of 1999 is -22 per cent. Even if tourism income continues to accrue at 1995 levels and no additional costs are incurred (i.e. no maintenance or rebuilding of tourist infrastructure are required), after 20 years the IRR is still 0 per cent. The net present value (NPV) of the investment in tourism at Dzanga-Sangha based on the same costs and revenues from 1992 to 1999, assuming a very favourable 10 per cent discount rate (NB: the actual lending rate in the region often exceeds 30 per cent) is $-\$ U S 286,088$. Tourist revenues would have to increase almost eightfold, to over $\$ \mathrm{US} 155,000$ per year until the year 2000, or revenues would have to exceed \$US61,000 per year to 2012 to generate a

I IRR is the interest rate expected for an investment consisting of a series of payments and income that occur at regular intervals over some time period. NPV is the value of a future stream of payments and income if you receive these benefits today. For example, a dollar today invested at 10 per cent interest yields $\$ 1.10$ a year from now, thus the NPV of the $\$ 1.10$ received 1 year from now is $\$ 1$. With a 10 per cent interest rate, you should be indifferent to receiving $\$ 1$ now or $\$ 1.10$ in 1 year, for given one you can obtain the other by either lending or borrowing. NPV is a useful tool for comparing the economic value of different investments with different costs and income streams. No investment should ever be made that results in a negative NPV or an IRR that is less than the present lending rate. NPV is calculated using,

$\mathrm{NPV}=\sum_{j=1}^{n} \frac{\text { values }_{j}}{\left(1+\text { rate }^{j}\right.}$

where $n$ is the length of the investment in years, values is the sum of payments ( - ve values) and income ( + ve values) accrued during time period $j$. Rate is the interest or discount rate. IRR is the interest or discount rate in the above equation that would result in an NPV of zero. 
Table 3 Tourist revenue generation and distribution in Dzanga-Sangha, Central African Republic

\begin{tabular}{|c|c|c|c|c|c|c|c|}
\hline \multirow[b]{2}{*}{ Year } & \multicolumn{4}{|c|}{ Tourist revenue (\$US) } & \multicolumn{3}{|c|}{ Revenue distribution (SUS) } \\
\hline & Entrance fees* & $\begin{array}{l}\text { Rentals and } \\
\text { services }\end{array}$ & Souvenir sales & Total & $\begin{array}{l}\text { Reserve } \\
\text { management }\end{array}$ & Local NGO & Forestry fund \\
\hline 1993 & 2763 & 680 & 643 & 4086 & 2705 & 1105 & 276 \\
\hline 1994 & 5952 & 5930 & 998 & 12,880 & 9904 & 2381 & 595 \\
\hline 1995 & 7695 & 10,689 & 2,128 & 20,512 & 16,665 & 3078 & 770 \\
\hline Total & 16,410 & 17,299 & 3769 & 37,478 & 29,273 & 6564 & 1641 \\
\hline
\end{tabular}

Source: Blom, 1998.

* In 1995 the one-time entrance fee was doubled for non-residents to $\$ 10$. The fee structure was again changed in 1996 to $\$ 16$ per non-resident (regardless of duration of stay), $\$ 1$ per national, $\$ 8$ per car, and $\$ 16$ per truck.

positive NPV. Given the assumptions in this example, tourism is not currently a viable enterprise in DzangaSangha because the NPV is negative and the IRR is less than the 10 per cent opportunity cost of capital (i.e. the lending rate).

Assuming that tourists visiting Dzanga-Sangha to see gorillas would be willing to pay an entrance fee comparable to that charged to see gorillas in Rwanda, Uganda and the DRC (i.e. \$US150-200 per visit), tourist visitation to the park would generate a positive NPV, if visitation rates did not decline from the 1994 maximum of 1090 . To produce a profit that could be applied to offsetting the \$US550,000-914,000/year management costs of the park, the number of tourists coming to see gorillas would have to increase threefold or fourfold. If we treat the capital costs of establishing a tourist infrastructure as a 'donor' gift and exclude them from estimates of the value of tourism, current tourist revenue distributed to the park accounts only for 24 per cent of management costs. Visitation rates would have to increase threefold to sixfold and entrance fees rise to between \$US180 and 240 per visitor for tourist fees to cover the present management costs of the park and still be able to allocate a portion of the entrance fees to the local NGO and forestry fund.

Tourism is also touted as a way to generate sustainable, alternative sources of income for local communities. However, the results from Dzanga-Sangha are not encouraging. Although 40 per cent of tourist entrance fees are allocated to a local NGO for development activities, this amounted to only \$US3078 in 1995 (Table 3). If donors had used the $\$ U S 390,000+$ spent on developing a tourist infrastructure to establish a trust fund, a conservative 7 percent rate of return (10 per cent interest minus 3 per cent recapitalization) would have generated $\$ U S 27,000$ + each year, in perpetuity. This would cover the lost salaries of the 14 tourism employees ( $\$$ US13,800/year) that constitute only 5 per cent of the local population, and would still gener- ate four times the revenue for the local NGO that is generated by entrance fees. Interest from a trust would not only exceed the value of entrance fees paid by tourists in 1995 (Table 3), it would also exceed the total multiplier effect on the local economy (i.e. the value of goods and services provided by the local community to tourists; Table 3). Moreover, revenues from a trust fund with a diversified investment portfolio are likely to be considerably less volatile than those from tourism, where demand is fickle and security in Central African Republic unpredictable. Revenue from a trust fund need not be allocated as a gift to the local community, which risks development of a dependency or rent-seeking mentality (Yates, 1996). Rather, community members could: (a) be paid a 'wage' to undertake conservation activities; or (b) be paid for the opportunity costs of forgoing exploitation of specific forest resources (e.g. bushmeat) - using collective culpability and censure to ensure compliance of individuals. In this way the trust fund 'reward' could be linked directly to community adoption of conservation-oriented behaviour.

Not only is the present tourist industry in DzangaSangha uneconomic, high travel costs relative to other destinations in Africa, the inability to visit multiple protected areas on a single international airfare, a boneshaking 8-12 $\mathrm{h}$ drive on a dry day from the nearest international airport, and civil unrest make it highly unlikely that tourist visitation will double or triple. It is also unlikely that tourists will be willing to pay over \$US100 per visit. Consequently, it may be unrealistic to assume that revenues will ever recover the costs of donor investment in tourist infrastructure, let alone contribute significantly to the recurring costs of park management.

\section{Tourist visitation and revenue generation in the Congo Basin}

Similarly, although the Lopé Reserve in Gabon supports large populations of elephant, gorilla and 


\begin{tabular}{|c|c|c|c|}
\hline Site & Period & $\begin{array}{l}\text { No. of } \\
\text { visitors } \\
\text { per year }\end{array}$ & $\begin{array}{l}\text { Revenues } \\
\text { per year } \\
\text { (\$US) }\end{array}$ \\
\hline Volcanoes NP, Rwanda & $1985-89$ & 5800 & 525,000 \\
\hline Virunga NP, Democratic Republic of Congo & $1986-90$ & 2800 & 250,000 \\
\hline Kahuzi-Biega NP, Democratic Republic of Congo & $1988-91$ & 2000 & 200,000 \\
\hline Bwindi NP, Uganda & $1994-96$ & 2800 & 450,000 \\
\hline Mgahinga Gorilla NP, Uganda & $1995-96$ & 1200 & 60,000 \\
\hline
\end{tabular}

Table 4 Gorilla tourism revenues

mandrills Mandrillus sphinx, and has direct charter flights and train access from Libreville, the privately owned air-conditioned tourist hotel currently loses money (L. White, pers. comm.). Only 450 tourists visited the Tongo chimpanzee reserve in DRC in 1990, generating less than \$US14,000 in fees (Weber, 1998). Primate tourism in Nyungwe forest in Rwanda attracted 2659 visitors in 1990, generating approximately $\$$ US10,000 in entrance fees, equivalent to 3 per cent of estimated management costs. Between 1989 and 1996 an average of 200 tourists visited Korup National Park in Cameroon each year (Culverwell, 1998). In 1990 entrance fees to Korup raised a mere \$US2800 (Weber, 1998). In 1998 no visitors crossed the only bridge into the southern section of Korup between February and June. National, expatriate and international tourist visits to Cameroon's protected areas have declined steadily between 1989 (9000) and 1996 (5000) (Culverwell, 1998). Only seven of the 14 national parks and reserves in Cameroon offer tourist accommodation, and most are operated by a governmental agency, MINTOUR, through safari-hunting concessionaires. None is comparable in quality to those available in other African wildlife tourism countries (Culverwell, 1998). In Odzala National Park in the Republic of Congo, projections for increasing gorilla tourism (C. Aveling, pers. comm.) suggest that if annual visitation rose from zero to 480 tourists and each paid $\$$ US1700 to visit the park for a week, over $\$ \mathrm{US} 300,000$ would be generated for park management and the national treasury. However, given present costs and taxation rates, the tour operator would be expected to receive only $\$$ US19,000 per year in profit (C. Aveling, pers. comm.). This meagre and economically unattractive 6 per cent return on investment is unlikely to encourage individuals or companies to incur the risks associated with establishing tourism in civil-war-torn Republic of Congo.

The one wildlife viewing success story in the region is gorilla tourism in the DRC, Rwanda and Uganda. The experience of tracking and sitting with a family of gorillas is so exceptional that tourists accept the risks of travelling in the Great Lakes region and are willing to pay the highest entrance fees in Africa (\$US120-250/ day). As a result, gorilla tourism has generated revenues that not only finance protected-area management costs but also contribute significantly to national treasuries (Table 4).

Prior to the civil war in the DRC and Rwanda, large numbers of tourists visited habituated gorilla families in Kahuzi-Biega and Virunga national parks in the DRC, and in Volcanoes National Park in Rwanda. At its peak, gorilla tourism in Rwanda generated \$US1 million in entrance fees alone, and contributed \$US3-5 million to the national economy (Butynski \& Kalina, 1998). Currently, unrest in eastern DRC has seen gorilla tourism shift to Mgahinga and Bwindi national parks in Uganda. In 1998 over 6000 tourists visited these two parks to see gorillas, generating over \$US1 million in entrance fees (A. Lanjouw, pers. comm.). Since 1994 Kahuzi-Biega has had virtually no tourists and, without their economic input, poaching and agricultural encroachment has recommenced $(\mathrm{Bu}-$ tynski \& Kalina, 1998). The recent slaughter of tourists visiting gorillas in Bwindi by Hutu rebels may, similarly, result in a crash in tourist visitation, a decline in revenues and reduction in the capacity of gorillas to pay for their own conservation. Insecurity in the eastern Congo Basin may benefit Odzala National Park in Republic of Congo, which now has groups of habituated gorillas and expects to generate revenues from tourism. Dzanga-Sangha special forest reserve in Central African Republic is beginning the process of habituating gorillas and hopes also to benefit financially from gorilla tourism.

Gorilla tourism has demonstrated that it can generate significant revenues and can assist species and habitat conservation, but civil strife and insecurity in the region threaten its viability both as a source of national income and as a means of financing conservation.

\section{Prospects for the future}

If tourism appears marginal in the most well established and accessible sites with abundant and charismatic wildlife (i.e. Lopé, Odzala, Dzanga-Sangha), then prospects for a viable tourist industry in more isolated, 
less well endowed protected areas in the Congo Basin are not encouraging. Tourism is only likely to be a major source of revenue when a protected area fulfils the criteria listed below.

- Contains charismatic species (i.e. gorilla, leopard Panthera pardus, okapi Okapia johnstoni, bongo);

- Guarantees wildlife viewing;

- Is close to an international airport or major tourist centre;

- Offers easy (short), comfortable and safe access;

- Provides internationally acceptable standards of food and accommodation;

- Is close to other tourist attractions such as beaches and cultural features;

- Offers unique landscapes; and

- Is moderately inexpensive (McNeely et al., 1992).

Many protected areas in the Congo Basin can offer tourists charismatic species (lowland gorilla, bongo, mandrills, giant forest hogs Hylochoerus meinertzhageni, okapi, etc.) but meet few of the other criteria. Travel to protected areas in the Congo Basin is arduous (even if possible), expensive and potentially dangerous. Civil wars, political coups, rebellions, and harassment by police, immigration and Customs officers are depressingly commonplace in central African nations. Current tourist information available in bookstores and on the Internet tells tourists that travel in the region is unsafe-a certain disincentive to prospective visitors to protected areas.

Given the problems discussed above, for the next 5-15 years at least, tourism in the Congo Basin is likely to be restricted to: expatriates living in-country and who are familiar with the challenges of travelling in the region; the occasional low-budget adventure tourist; and very rarely, a film crew (M. Fay, pers. comm.). Unless security and access improve substantially it is unlikely that parks, other than those able to offer an intimate gorilla-viewing experience, will see the threefold or fourfold increase in visitation and the fifteenfold to twentyfold fold increase in tourist expenditure needed to recoup infrastructure investment costs, and contribute significantly to offsetting the recurring costs of park management. Science tourism, such as Earthwatch or School for Field Studies, is unlikely to be feasible in most protected areas in the region, given their isolation and insecurity. It thus seems highly unlikely that tourism will generate significant net benefits to protected areas, given the substantial capital costs required to put in place tourist infrastructure, and the fact that conservation organizations have little control over national security. In contrast, safari hunting (i.e. tourism where the resource is consumed directly rather than merely observed by the visitor) may provide a significant source of revenue for wildlife management in areas endowed with trophy-quality bongo, and elephant, if well regulated (Wilkie \& Carpenter, 1999). This is particularly true because hunters are often much more willing to 'rough it' than are most ecotourists (B. Lubin, Les Guides Associes de Haut Chinko, pers. comm.).

According to Wallace $(1993,1998)$, ecotourism is distinguished from other forms of tourism in that: (a) it improves protected-area management; and (b) it provides economic benefits to local residents asked to forgo resource use. At present, ecotourism in the Congo Basin fails to achieve the former and only marginally achieves the latter. Tourism in most locations throughout the Congo Basin is a net financial cost to protected-area management. Even the intangible value of word-of-mouth advertising and advocacy by tourists is unlikely to stimulate donor contributions sufficient to offset the costs to develop tourist infrastructure in isolated protected areas in the region. Consequently, organizations should conduct more thorough financial and economic appraisals of the potential value of tourism (see, for example, IRG, 1992), before using scarce conservation funds, which could be spent better elsewhere, into tourist infrastructure development.

\section{Acknowledgements}

Thanks to Conrad Aveling, Tom Butynski, Allard Blom, Lee White, Bryan Curran, Roger Fotso, Andrew Plumptre and four anonymous reviewers from Oryx for commenting on the manuscript. Thanks to World Wildlife Fund-US, the Wildlife Conservation Society and ECOFAC for access to unpublished reports. This study was supported in part by funding from the United States Agency for International Development CARPE (Central African Regional Program for the Environment) project.

\section{References}

ART (1998) Costs of Conserving State Protected Areas in Southern Africa. Africa Resources Trust, Harare.

Blom, A. (1998) The impact of tourism on protected area management and the local economy in Dzanga-Sangha (Central African Republic). Conservation Biology (in press).

Butynski, T.M. \& Kalina, J. (1998) Gorilla tourism: a critical look. In Conservation of Biological Resources (eds E. J. Milner-Gulland and R. Mace), pp. 294-313. Blackwell Science Ltd, Oxford, UK.

Byrne, P.V., Staubo, C. \& Grootenhuis, J.G. (1996) The economics of living with wildlife in Kenya. In The Economics of Wildlife: Case Studies from Ghana, Kenya, Namibia, and Zimbabwe (ed. J. Bojo), pp. 39-78. World Bank, Washington, DC. 
Culverwell, J. (1998) Long-term Recurrent Costs of Protected Area Management in Republic of Cameroon: Monitoring of Protected Areas, Donor Assistance and External Financing, Ecological and Management Priorities of Current and Potential Protected Area System. WWF Republic of Cameroon/MINEF, Yaounde.

IRG (1992) Ecotourism: a viable alternative for sustainable management of natural resources in Africa. International Resources Group, Washington, DC.

McNeely, J.A., Thorsell, J.W. \& Ceballos-Lascurain, H. (1992) Guidelines: Development of National Parks and Protected Areas for Tourism. World Tourism Organization and United Nations Environment Programme, Madrid.

Norton-Griffiths, M. (1995) Property Rights and Wildlife Conservation Options in Kenya. CSERGE (Centre for Social and Economic Research on the Global Environment), East Anglia, UK.

Norton-Griffiths, M. (1997) Economic incentives to develop the rangelands of the Serengeti: implications for wildlife conservation. In Serengeti II: Research, Management and Conservation of an Ecosystem (eds A. R. E. Sinclair and P. Arcese), pp. 588-604. University of Chicago Press, Chicago.

Norton-Griffiths, M. \& Southey, C. (1995) The opportunity costs of biodiversity conservation in Kenya. Ecological Economics, 12, 125-139.

Ruitenbeek, H.J. (1992) The rainforest supply price: a tool for evaluating rainforest conservation expenditures. Ecological Economics, 6, 57-78.

Wallace, G.N. (1993) Wildlands and ecotourism in Latin America: investing in protected areas. Journal of Forestry, 91, 37-40.

Wallace, G.N. (1998) Toward a Principled Evaluation of Ecotourism Ventures. Colorado State University, Denver.

Weber, W. (1998) Conservation des Primates et Ecotourisme en Afrique. Wildlife Conservation Society, Bronx.

Wilkie, D.S. \& Carpenter, J.F. (1999) The potential role of safari hunting as a source of revenue for protected areas in the Congo Basin. Oryx, 33, 339-345.
Wilkie, D.S. \& Carpenter, J.F. (in press) The under-financing of protected areas in the Congo Basin: so many parks and so little willingness-to-pay. Biodiversity and Conservation.

Yates, D. (1996) The Rentier State in Africa: Oil Rent Dependency and Neocolonialism in the Republic of Gabon. Africa World Press, Trenton, NJ.

\section{Biographical sketches}

David S. Wilkie, Adjunct Associate Professor, Boston College, is a wildlife ecologist with a post-doctoral anthropology specialization in human behavioural ecology. He has over 15 years of research experience in the socio-economic aspects of household-level natural resource use in central and west Africa, and in central and south America. His research in the Congo Basin has focused on: determining the local and regional impact of forager and farmer subsistence practices on forest plant and animal composition, distribution and abundance; and the household economic determinants of Efe hunter-gatherer adoption of agriculture into their suite of subsistence activities. Other research interests include: examining the impacts of trade and the commercialization of non-timber forest products on forest animal populations; the role that logging plays in promoting bushmeat markets; the income and price elasticities of demand for bushmeat; and the use of satellite imagery and aerial photography to model the location, extent and rate of land transformation within rain forests.

Julia F. Carpenter gained a BA in Geography from Boston University and an MA in Environmental Policy from Tufts University, USA. Her research interests have focused on looking at options for conserving biodiversity in developing countries and on studying the relationship between rural resource users and biodiversity conservation. 